\title{
Housing Ex-Offenders in the Netherlands: Balancing Neighbourhood Safety and Human Rights
}

\author{
J. H. S. van Tongeren ${ }^{1}$ \\ Published online: 23 April 2020 \\ (C) The Author(s) 2020
}

\begin{abstract}
The Universal Declaration of Human Rights recognises stable housing as a prerequisite for an adequate standard of living. A home provides shelter and enables personal development, thus contributing to the individual's well-being. Despite this, however, many struggle to find a place to live. In the Netherlands, people with a history of criminal or anti-social behaviour ('ex-offenders') are among those whose search for housing is most problematic. They are sometimes viewed as unreliable tenants or denied access to housing out of fear for recidivism. At the same time, Dutch local authorities - responsible for maintaining public order-may (aim to) prevent an ex-offender from (re) settling in their municipality. Recent legislation in the Netherlands furthermore allows local authorities to screen and exclude people from certain urban areas based on their past behaviour. How do Dutch private and administrative actors decide between ex-offenders' housing rights on the one hand and other persons' (feelings of) safety and public order on the other? And how do the laws and policies in the Netherlands concerning the housing of exoffenders relate to the state's human rights obligations? Using doctrinal legal research methods and applying a normative, human rights framework, this paper concludes that while there are no out-right violations of fundamental rights and freedoms, several approaches in the Netherlands do appear to be problematic and at odds with international obligations.
\end{abstract}

Keywords Ex-offenders $\cdot$ Neighbours $\cdot$ Housing $\cdot$ Safety $\cdot$ Human rights $\cdot$ Reintegration

J. H. S. van Tongeren

j.h.s.van.tongeren@ rug.nl

1 Department of Legal Methods, Faculty of Law, University of Groningen, Turftorenstraat 21, PO Box 716, 9700 ASGroningen, The Netherlands 


\section{Introduction}

According to the 1948 Universal Declaration of Human Rights (UDHR), having access to housing is a prerequisite for an adequate standard of living. ${ }^{1}$ Everyone should be able to live "somewhere in security, peace and dignity" (CESCR 1991, para. 7). In spite of this universal recognition, however, many still struggle to find a decent place to live (Kenna 2008). In the Netherlands, people with a criminal record or a history of anti-social behaviour are among those whose search for housing is most problematic. Dutch housing providers often view these 'ex-offenders' as unreliable and, therefore, unwelcome tenants. What is more, the arrival or presence of an ex-offender regularly causes concern among residents and may in some cases even threaten the safety or public order in the neighbourhood. ${ }^{2}$ As a consequence, Dutch local authorities sometimes seek to prevent the ex-offender from (re) settling in their municipality. In order to determine to what extent private and administrative law in the Netherlands balances the rights and interests of both the ex-offender and his or her (future) neighbours, this paper examines Dutch law and policies from a human rights perspective.

As shown by previous research, having a roof over one's head is essential for a person's wellbeing; it provides shelter from "external physical threats" (Hohmann 2013, p. 4) and allows for personal development. For an ex-offender, having access to housing is considered a prerequisite to a successful return into society and necessary to "become a lawful and productive member of [that] society" (Cain 2003, p. 148). Those who do enjoy a stable living situation have their recidivism risk significantly reduced (Baldry et al. 2006; Roman and Travis 2006; Metraux and Culhane 2004). Besides offering shelter, a home is crucial in organising other key aspects of life. A lack of a fixed address, for example, affects the chances of securing an income by reducing the probability of the ex-offender finding a job (Bushway et al. 2007). It furthermore frustrates the ex-offender's efforts to conquer alcohol or drug addiction (Nelson et al. 2011). It is not surprising, then, that housing has been characterised as the "lynchpin that holds the reintegration process together" (Bradley et al. 2001, p. 1).

Despite the widely recognised importance of housing for the reintegration process, exoffenders' search for adequate accommodation remains problematic. A study conducted by More and Weijters (2011), for instance, showed that $15.5 \%$ of Dutch ex-offenders released from detention had no access to any form of housing. What is more, an increased number of ex-offenders became dependable on unstable and temporary housing such as homeless shelters. It should be noted, however, that these are only the estimates based on the expectations of social service workers. Actual data concerning ex-offenders' housing situation after they served their sentence is not available in the Netherlands. ${ }^{3}$

With regard to landlords' attitudes towards rental applicants with a background of criminal or anti-social behaviour there is little data available as well. It is, however, assumed that such a history stigmatises the ex-offender in a way that it affects his or her chances of finding a home (Crowell 2017, p. 1109). One American study on property owners' views on released exoffenders seems indeed to support this hypothesis (Clark 2007). It found that housing

\footnotetext{
${ }^{1}$ Article 25 (1) UDHR

${ }^{2}$ It is not always the ex-offender who poses a threat to the community; public order may also be threatened by strong reactions of (other) residents towards the ex-offender. See Boone, Van de Bunt \& Siegel 2014.

${ }^{3}$ This is why the periodical aftercare monitor for former prisoners produced by the Dutch Research and Documentation Centre (WODC) no longer includes information concerning ex-offenders' housing situation after release: "[w]ith regard to housing, it was not possible to find information on the situation of aftercare candidates after release from prison" (Weijters et al. 2018, pp. 26, 70).
} 
providers tend to attribute negative characteristics to applicants with a criminal record: "These negatives include probation or parole requirements that may interfere with full-time employment, a total lack of credit due to imprisonment, and disapproving neighbor reactions" (Clark 2007, p. 25). Two field experiments focusing on Dutch landlords revealed that private housing providers in the Netherlands are also hesitant to rent their property to people with a criminal conviction (Dirkzwager et al. 2015). The study showed that rental applicants who spent time in prison were rejected more often than applicants without a (known) criminal history. Although only private, non-social housing providers were considered, the study presented in this paper suggests that Dutch housing associations ${ }^{4}$ sometimes also appear reluctant to house exoffenders. ${ }^{5}$

Other barriers that Dutch ex-offenders have to overcome are put up by national and local administrative law and policies. It has been established in several (Dutch) studies that local authorities - responsible for maintaining the public order-sometimes (have to) use their administrative powers such as the issuing of area exclusion orders to protect the safety in the neighbourhood and to prevent disorder (Elbers et al. 2016; Huls and Brouwer 2013). In 2016, it has moreover become possible for Dutch authorities to ban possible tenants from certain inner-city areas on a systematic basis. The (extended) Urban Areas Special Measures Act allows for the exclusion of people on the basis of their (lack of) income as well as their past criminal or anti-social conduct.

\section{Objectives and Research Methods}

The objective of this paper is threefold. First, it aims to build on existing descriptive, doctrinal legal theory (Wacks 2017, pp. 6-7) by examining the Dutch legal framework concerning the housing of ex-offenders (sections 5, 6, and 7). Doctrinal legal research is unique in the sense that it seeks to explain what the law is, why it is as it is, and what its potential consequences are. According to Hutchinson and Duncan, doctrinal legal theory "provides a systematic exposition of the rules governing a particular legal category, analyses the relationship between rules, explains areas of difficulty and, perhaps, predicts future developments" (Hutchinson and Duncan 2012, p. 101). A comprehensive understanding of the law provides a solid basis for future (empirical) research as well: one has to know how the law reads before being able to thoroughly study its application. This paper should serve as a groundwork for such (empirical) research. Moreover, by elaborating on the difficulties surrounding the housing of ex-offenders in the Netherlands, this paper may contribute to the growing body of international academic research on this topic. While most of these studies focus on the various approaches adopted in North-America, the laws and policies in many European jurisdictions - including that of the Netherlands - remain largely unstudied. This paper aims to fill that gap.

The second purpose of this paper is to provide a normative analysis of the law. According to Tyler, legal research "involve [s] efforts to understand the best balance of rights and obligations under the framework defined by law" (Tyler 2017, p. 130). By analysing the Dutch state's international and European human rights obligations, such a normative framework has been

\footnotetext{
${ }^{4}$ Housing associations own most of the social housing stock in the Netherlands. While they are private, nonprofitmaking organisations and are independent from the Dutch government, they do have to comply with specific requirements mentioned in the Dutch Housing Act (Woningwet).

${ }^{5}$ See also Van Tongeren and Vols 2018, pp. 176-179
} 
constructed (section 4). Against the background of this framework, it will be determined to what extent the laws and the policies of private and administrative actors in the Netherlands are in accordance with human rights (section 8).

Lastly, the paper aims to theorise on the possible broadening of the term '(ex-) offender' (section 3). It argues that not only persons who received a criminal sanction are being excluded from important aspects of (social) life, but also those who have been disciplined via administrative or private law. Consequently, this paper primarily focuses on the various administrative and private law approaches towards the housing of ex-offenders. Seeing that the shift from the traditional (criminal) way of sentencing towards alternative methods can also be observed in other jurisdictions (Carey 2004, p.1) the discussion provided in this paper is of interest from an international perspective as well.

\section{Defining the '(Ex-)Offender'}

The term 'offender' - or the more or less synonymous concepts 'criminal', 'perpetrator', 'culprit', and 'delinquent' - is much used in (legal) research. While it is generally understood to mean "one who violates the criminal law" (Lindesmith and Warren Dunham 1941, p. 307), only few studies actually explain what characterises an 'offender'. Crowther in his Introduction to Criminology and Criminal Justice defines an 'offender' as "someone who carries out an act, which is usually (but not inevitably) in this context a criminal act" (Crowther 2007, p. 48). However, "it is not until individuals have been identified as suspects, charged with a crime, been tried, found guilty and sentenced that they are officially 'offenders' in the view of the state (and, in a sense, of the wider public)" (Crowther 2007, p. 49).

Most definitions (implicitly) referred to in legal research fail to take into account two important shifts in policies and practices dealing with crime and (other) deviant behaviour. Firstly, whereas traditional definitions usually require criminal law to be involved, alternative approaches for law enforcement are becoming more and more prominent. Secondly, sanctions are no longer solely reserved for criminalised behaviour; other forms of deviant conduct, such as certain anti-social acts, may lead to (administrative or private) sanctions as well. It is for these two reasons that this paper argues for the adoption of a new, broader definition next to the traditional, narrow interpretation.

In his book The Culture of Crime (Garland 2001), David Garland already elaborated on the significant change he observed in the way crime and criminals are being regulated. Crime control no longer constitutes an area monopolised by criminal law and "criminal justice specialists" but is increasingly becoming an affair of (other) state and civil actors as well (Garland 2001, p. 170). As Garland notes, "[t] his new sector occupies an intermediate, borderline position, poised between the state and civil society, connecting the criminal justice agencies with the activities of citizens, communities and corporations" (Garland 2001, p. 170).

A prominent manifestation of this movement away from crime control by means of traditional, criminal law is the increased use of (punitive) administrative and private law instruments (Klein 1999; Mann 1992). This shift can be observed in many countries and the Netherlands is no exception (Van der Vorm 2018; Bröring and Keulen 2017). Dutch examples include area exclusion orders aimed at preventing an individual from entering or settling in a municipality and home closure orders, used to close premises utilised for criminal activities. Dutch public authorities may in principle also use private law instruments to enforce (their) laws and policies. Instead of achieving "control of anti-social behaviour"-Mann argues, the 
traditional purpose of criminal law "in its most general sense" (Mann 1992, p. 1807) - by means of the often difficult and time-consuming criminal justice system, a faster and more direct alternative is often preferred. Seeing the increased use of these (punitive) administrative and private law sanctions, it can be argued that those lawbreakers who face punishment via these non-criminal methods should also be characterised as 'offenders'. 6

In addition to the traditional interpretation of the 'offender' concept not including those who are being disciplined by means of alternative, non-criminal methods, it also does not take into account the fact that non-criminalised deviant behaviour may be susceptible to punishment as well. While the standard definition of an 'offender' only concerns those who have violated the criminal law, authorities sometimes also sanction certain conduct that has not been criminalised. One (Dutch) example is the use of administrative sanctions to deal with people causing (serious) nuisance in and around their homes. Seeing that it is not always possible to respond to this kind of behaviour by means of the criminal justice system, the Dutch legislator in 2017 allowed local authorities to issue administrative sanctions, such as an order to remove sound equipment or to confiscate a person's dog.

Considering the two shifts in policies and practices dealing with crime and (other) deviant behaviour set out above, this paper argues that the traditional characterisation of an 'offender' as a person sentenced for violating the criminal law no longer suffices. It, therefore, provides a new, broader interpretation of this concept, describing the offender as a person who committed a criminal offence or a non-criminalised deviant act and who, as a result of this behaviour, has received a sanction via the traditional, criminal justice system or via other (legal) means such as administrative or private law instruments.

Adopting this broader definition does of course have several implications. Individuals who are labelled '(ex-)offender', for instance, often have to cope with strong stigmatisation (see, e.g., Moore et al. 2016), especially when this theoretical label is applied outside the academic arena as well. Widening the scope of the 'offender' concept carries with it the risk of more individuals being stigmatised based on their characterisation as an ex-offender. Another issue that needs to be taken into consideration when applying the proposed '(ex-)offender' definition concerns the consequences of bringing individuals with distinct reintegration needs under one banner. However, differentiating between varying reintegration needs has ever been an area of concern when studying the reintegration of ex-offenders. A person sentenced to serve time in prison may have a more pressing need to reintegrate than someone who received a community service order; finding adequate housing is likely more difficult for someone who committed a sex-related crime than for an individual who was disciplined because of neighbour nuisance. Acknowledging these differences nevertheless becomes more imperative when opting for a wider definition of the '(ex-)offender'. Adopting this wider definition, then, has its advantages but also requires certain already problematic issues to be addressed (more) explicitly.

\section{Establishing the Human Rights Framework}

Community residents usually seem aware of the importance of adequate housing for exoffenders' reintegration process. However, they can feel uncomfortable having someone with

\footnotetext{
${ }^{6}$ Besides these sanctions "replacing a significant part of the criminal law in critical areas of law enforcement" they are "sometimes more severely punitive than the parallel criminal sanctions for the same conduct" as well (Mann 1992, p. 1798).
} 
a record of criminal or anti-social behaviour living next to them. Their own interests - to be and feel safe at home and in the neighbourhood - may conflict with the ex-offender's housing needs. To maintain peace and quiet in the community, landlords as well as (local) authorities sometimes prevent the ex-offender from (re) settling in the area. This can be at odds with the state's obligation to protect the ex-offender's fundamental rights, such as his or her housing rights, the right to privacy in relation to have their criminal past forgotten, or the right to be presumed innocent and, thus, not be confronted with a default position that they will reoffend. The human rights analysis that follows primarily focuses on the ex-offender's right to housing and right to freedom of residence, since the study presented here is first and foremost concerned with their access to housing in relation to other persons' (feelings of) security. Even though much has been written on these housing rights (see e.g. Hohmann 2013; Adams 2009; Kucs et al. 2008), their exact interrelationship could use clarification.

\section{Protecting Community Residents}

All states have a core obligation to protect their citizens against (possible threats of) harm. This idea can be based on the conceptualisation of two rights. Besides a moral right to be protected against harm by third parties, citizens also have a legal right to a peaceful and safe living environment.

The moral right of citizens to be protected against (possible threats of) an ex-offender can be constructed using social contract theory. According to this theory, states have an obligation to protect their citizens from any kind of harm, including harm caused by other citizens. This obligation to protect is the fundamental principle underlying each government (Rousseau 2003; Locke 1993; Hobbes 1981). If citizens' well-being is being threatened or harmed, state authorities have to take action. If they refuse or neglect to do so, the state "[fails] to fulfil those duties or obligations which it possesses in virtue of being a state" (Lammar-Heindel 2012).

When applying this to the context of the housing of ex-offenders, one may conclude that it is the state's duty to act when an ex-offender's return into society results in a (possible) threat of residents' (feelings of) safety. Although it does not entitle the ex-offender's (future) neighbours with a fundamental right as such which they can invoke to force the state to act, it does provide public authorities with an intrinsic obligation to take into account citizens' safety and quality of life when housing an ex-offender in their neighbourhood.

Besides this moral responsibility, states also have a legal obligation to protect their citizens against (possible threats of) harm. Article 8 of the European Convention on Human Rights (ECHR) holds, among others, the right to freedom of quiet enjoyment of one's private life and home. States have a negative obligation to refrain from illegitimately interfering with a person's right to peaceful enjoyment of his or her home. Moreover, Article 8 ECHR places states under the positive obligation to act upon infringements of this right by others. These infringements do not necessarily have to be physical; case law shows that breaches caused by noise, smells, and emissions could also constitute a violation of the right to quiet enjoyment. ${ }^{7}$ As Hohmann points out, "these cases may be interpreted as concerning the protection of the quality of one's living environment” (Hohmann 2013, p. 69).

\footnotetext{
${ }^{7}$ See, e.g., ECtHR 22 November 2011, no. 24202/10 (Zammit Maempel v. Malta); ECtHR 20 May 2010, nos. 43,449/02 and 21,475/04 (Mileva et al. v. Bulgaria); ECtHR 16 November 2004, no. 4143/02 (Moreno Gomez v. Spain)
} 
Based on the case law of the European Court of Human Rights (ECtHR) it can be concluded that the lack of action by state authorities as a reaction to an infringement by a neighbour-whether an ex-offender or not-could amount to an interference of the right to the quiet enjoyment of the home. However, whether the mere presence of an ex-offender is enough reason for the Court to conclude that there has been a violation of this right remains unclear.

In addition to the right to the quiet enjoyment of one's home the International Covenant on Economic, Social, and Cultural Rights (ICESCR) also offers citizens a legal right to a safe and secure living environment. Article 11 of the ICESCR holds the right to housing. According to the Committee on Economic, Social, and Cultural Rights (CESCR), this fundamental right should be interpreted in an extensive manner: it should be understood as a right to adequate housing (CESCR 1991, para. 7). States have a positive obligation to ensure that their citizens can live in a home with "adequate privacy" and "adequate security" (CESCR 1991, para. 7). A further elaboration on this right to housing is provided in the next sub section.

\section{Respecting Ex-Offenders' Housing Rights}

Community residents' rights are often at odds with the ex-offender's housing rights. 'Housing rights' can be understood as all rights and entitlements related to housing, entailing both negative and positive obligations for state authorities. They include the right to housing and the right to freedom of residence.

\section{Ex-Offenders' Right to Housing}

According to the CESCR, several criteria have to be met if the right to adequate housing is to be sufficiently ensured. These criteria include accessibility, habitability, and legal security of tenure (CESCR 1991, para. 8). Accessibility here not only means that a home should be physically accessible to, for instance, disabled persons, but also that suitable accommodation should be available to other (disadvantaged) groups, such as victims of natural disasters and the mentally ill (CESCR 1991, para. 8, under (e)). ${ }^{8}$

The right to housing entails both negative and positive obligations for signatory states; authorities have to "respect, protect and fulfil" this fundamental right (OHCHR 2009, pp. 3337). The negative obligation to respect requires states to "refrain from interfering directly or indirectly with the enjoyment of the right to adequate housing", whereas the positive obligation to protect demands that states take measures to prevent third parties from interfering with this right. The obligation to fulfil calls for "appropriate legislative, administrative, budgetary, judicial, promotional, and other measures to fully realise the right to adequate housing" (OHCHR 2009, pp. 33-34). States have to take "whatever steps necessary" to provide their citizens with the full enjoyment of their right to adequate housing (CESCR 1991, para. 11); "any retrogression in housing rights would constitute a human rights violation" (Olds 2010, p. 175). Consequently, states should withhold from developing measures, policies, or practices

\footnotetext{
${ }^{8}$ Whether ex-offenders qualify as a disadvantaged group remains unclear. A letter from the UN Human Rights Committee (2015) strongly suggests that they do; however, it could also be argued that discrimination based on a criminal record does not imply discrimination on the ground of a "specific character" but 'only' qualifies as discrimination on (past) behaviour. See for the Committee's letter

https://www.lawsociety.com.au/cs/groups/public/documents/internetpolicysubmissions/1029302.pdf (accessed on 31 July 2017)
} 
that would result in a deterioration of the current housing situation in the country (Kucs et al. 2008, p. 103). ${ }^{9}$

The right to housing has also been codified in European human rights documents. Especially the European Committee on Social Rights (ECSR), responsible for monitoring state conformity with the European Social Charter (ESC), has produced a great body of case law on housing related issues, seeing that the right to housing has been laid down in Article 31 ESC (Hohmann 2013, pp. 49, 52). While the ECSR argues that the Article 31 ESC should not be understood as placing upon states any obligation of results, it does compel them to realise the right to housing in "a practical and effective, rather than purely theoretical, form". ${ }^{10}$ According to the ECSR, this includes a positive obligation for states to provide adequate housing to the most marginalised. ${ }^{11}$ States should moreover pay close attention to the consequences of their policies concerning the housing situation of the most vulnerable, especially those who suffer exclusion and poverty (Council of Europe 2008, p. 170).

While the ESC includes positive obligations for states to realise the right to housing, the ECHR does not explicitly mention a right to housing (Rainey et al. 2017, p. 403). However, the ECtHR does recognise that some provisions do protect housing related interests, most significantly the already discussed Article 8 ECHR (Hohmann 2013, pp. 67-75). Even though this provision does not hold an enforceable right to have access to housing, it does provide a right to respect for one's home; as such, it entails some (albeit minimal) positive obligations for the state (Hohmann 2013, p. 69; Rainey et al. 2017, p. 403).

\section{Ex-offenders' Right to Freedom of Residence}

In addition to the right to adequate housing, the right to freedom of residence could also be identified as one of the primary housing rights. This right has first been laid down in Article 25 (1) UDHR, which provides individuals with an enforceable right to choose where on the territory of the state they want to take up residence. Whether in a city, a town, or in the countryside, authorities are in principle not allowed to ask for any special housing permit (Alfredsson and Eide 1999, p. 272).

The freedom of residence has also been codified in Article 12 (1) of the ICCPR. It holds that states have both a negative and a positive obligation: they should abstain from taking measures that prevent the settlement of (certain groups of) individuals in a particular area (HRC (UN Human Rights Committee) 1999, para. 7) but also need to protect the right to freedom of residence against unlawful interferences by private actors (HRC (UN Human Rights Committee) 1999, para. 6). Article 12 (3) ICCPR allows for restrictions when these are provided by law and necessary to protect national security, public order, public health or morals, or the rights and freedoms of others.

Lastly, the right to freedom of residence has been laid down in Article 2 (1) of the Fourth Protocol to the ECHR. Although similar to Article 12 (1) ICCPR, it adds two more grounds for restrictions: public safety and the prevention of crime. It also adds that restrictions have to be necessary in a democratic society (paragraph 3). Paragraph 4 allows restrictions in "particular areas" if these are in accordance with law and justified by the public interest in a democratic society (Figure 1).

\footnotetext{
${ }^{9}$ See extensively Hohmann 2013, pp. 17-20

${ }^{10}$ ADT v. France, para. 59

${ }^{11}$ ECSR 5 December 2007, Case No. 39/2006 (FEANTSA v. France), para. 56
} 
Citizens

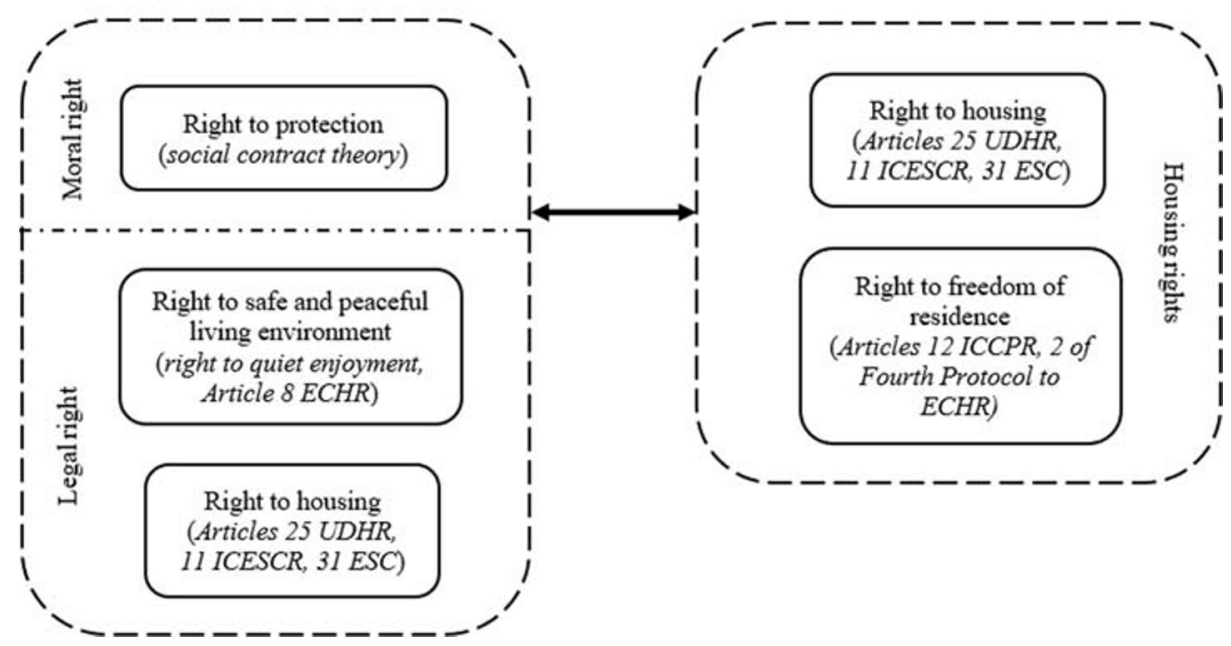

Fig. 1 The conflicting rights of ex-offenders and their (future) neighbours

\section{Housing Ex-Offenders I: Findings From a Private Law Perspective}

The studies discussed in the introduction of this paper showed that landlords appear reluctant to accommodate people with a criminal record. To identify the criteria used by Dutch courts to determine whether a housing provider was allowed to deny an ex-offender housing relevant (case) law has been collected and analysed, using the official database on www.rechtspraak.nl. The following fixed terms were used: "house + convicted", "house + criminal", and "house + offender". After filtering for private law cases, the court decisions concerning a legal conflict between a landlord and a tenant based on the tenant's (past) behaviour were manually selected. This resulted in twenty-seven cases.

Before examining some of these cases more closely, it is important to stress that although a case law analysis may provide insights into how the law should be interpreted and applied, this method has its limitations. One limitation is that the analysis only considers disputes that actually made it to court; another is that the sample might not be representative because the examined cases have not been randomly selected. Whereas all decisions of the Dutch Supreme Court are published in the online database, only a small percentage of lower court judgements is published online. ${ }^{12}$ The Dutch judiciary is responsible for selecting these cases using the database's official selection criteria. ${ }^{13}$ A court ruling should, for instance, be published when it contributes to the development of the law or when it has received media attention "in the broadest sense".

Considering that court decisions published in the online database are not randomly selected, one should be very careful in making empirical claims on the total population of cases based on an assessment of the published cases. The case law analysis presented below nevertheless

\footnotetext{
${ }^{12}$ In 2017, 4.1\% — or approximately 61.500 - of all lower court rulings produced that year had been published in the online database: Kengetallen Gerechten 2017, p. 50, via https://www.rechtspraak.nl/Organisatie-encontact/Organisatie/Raad-voor-de-rechtspraak/Jaardocumenten. Accessed 8 Sept 2019.

${ }^{13}$ Besluit selectiecriteria uitsprakendatabank Rechtspraak.nl 2012, via https://www.rechtspraak. nl/Uitspraken/paginas/selectiecriteria.aspx (accessed on 8 September 2019)
} 
does allow for doctrinal legal claims to be made, especially when considering the similarities between the cases and the different courts' decisions. Of the twenty-seven cases, eighteen are particularly relevant for this paper and have been examined in more detail. These cases can be divided into two categories. The first category of fourteen cases concerns tenants who had access to a rental home, but whose landlord requests the court to annul the tenancy agreement and order the tenant's eviction. The second category of four cases focuses on ex-offenders who lack access to stable housing and are either homeless or living in temporary housing. It includes ex-offenders whose rental application was rejected because of the (potential) threat they posed to other people's safety or to the quality of life in the area.

\section{The First Category: Offenders Who Lose Their Home}

A first challenge for people who do have access to housing the instant they receive a sanction is to maintain it. This particularly holds true for individuals sentenced to serve time in prison. There are plenty of examples in which an offence committed by a tenant directly leads to his or her eviction, most notably in drug-related cases (see Bruijn et al. 2018). However, there are also cases in which the offender's loss of his or her home is the result of the sanction that follows the offence. This is, for instance, the case when a tenant is sentenced to serve time in prison and is evicted because of his inability to physically occupy the rental accommodation. Although it is not the offence committed by the tenant that is the immediate cause of the (possible) eviction, the offender's loss of his or her home can in these cases be considered 'collateral damage' of his or her conviction.

According to Dutch landlord-tenant law, any shortcoming in the fulfilment of the tenancy agreement may constitute a ground for an annulment and, consequently, for eviction. Only if the shortcoming is of such a minor nature that it would not justify the consequences may the tenancy agreement not be annulled. ${ }^{14}$ Whether detention is a serious enough shortcoming appears to depend on the specific circumstances of the case.

In one dispute before the Court of Appeal of The Hague, the applicant had been sentenced to prison and is consequently unable to use his rental home as his primary residence. ${ }^{15}$ The housing association consequently requests the court(s) to annul the tenancy agreement and to evict the applicant. The Court of Appeal rules that the commitment of a tenant to actually live in his or her home is a core obligation of the tenancy agreement. Seeing that there are no "exceptional circumstances" demanding the Court of Appeal to decide otherwise, it concludes that the applicant comes short in the fulfilment of his obligations as a tenant and orders his eviction.

In another case, before the District Court of Zeeland-West-Brabant, ${ }^{16}$ the applicant had been sentenced to 20 months in prison. During his release on parole, he is to be treated for his psychological problems and is only able to stay in the accommodation during the weekends. When assessing the housing association's request for eviction, the District Court considers that even though the applicant came short in the fulfilment of his obligations, an eviction would seriously frustrate his resocialisation efforts and treatment. Seeing these "exceptional circumstances", the District Court decides against the eviction.

\footnotetext{
${ }^{14}$ Article 6:265 Dutch Civil Code. The tenant has to sufficiently motivate this proportionality defence: Vols 2015, pp. 55-62 (see also Vols 2019).

${ }^{15}$ Court of Appeal The Hague 8 July 2014, ECLI:NL:GHDHA:2014:2860

${ }^{16}$ District Court Zeeland-West-Brabant 5 April 2017, ECLI:NL:RBZWB:2017:4464
} 
The case law shows that when deciding upon a housing provider's request to evict the (incarcerated) tenant, Dutch courts - if so requested by the tenant-perform a weighing of interests. If the tenant appears to come short in the fulfilment of his or her obligations, the court will grant the landlord's request. Only in case of exceptional circumstances will the court decide otherwise.

\section{The Second Category: Ex-Offenders Who Are Refused a Home}

The second category of four cases concerns ex-offenders who are trying to find stable housing, but face rejection by property owners because of their past behaviour. Housing providers in the Netherlands are in principle free to rent their homes to the most qualified applicant; they enjoy contractual freedom. Social housing providers, on the other hand, do have a statutory obligation to provide affordable housing to people experiencing difficulties finding suitable accommodation. In order to fulfil this obligation as well as to ensure the safety of tenants and the general quality of life in the direct proximity of the rental premise, ${ }^{17}$ social housing providers need to balance all the interests at stake. To determine how social housing providers aim to do so, one illustrative case is presented here.

The case revolves around an applicant who has repeatedly been convicted for sexual abuse of minors. ${ }^{18}$ After his criminal trial—which received much publicity - the applicant is forced to live on the streets for some time. In 2014, he applies for a home owned by a housing association and situated in a child-friendly neighbourhood. The housing association, however, is concerned that the arrival of a paedophile sex offender will result in social unrest in the area and decides to reject his application. The applicant subsequently claims before the court that he has been wrongfully denied access to housing.

The court first determines that when deciding whether to rent a home to an ex-offender, a housing association should carefully weigh the interests of all parties involved and take into account all relevant circumstances. It then considers that while the housing association is allowed to take into consideration residents' feelings of discomfort or fear, these feelings should not be granted a decisive role in the decision-making process. ${ }^{19}$ If the housing association concludes that safety weighs heavier than the ex-offender's housing need, it may reject the application. However, seeing its statutory obligation to provide affordable housing to, among others, ex-offenders, the social housing provider is then obliged to offer the rejected applicant alternative housing. Only if the ex-offender refuses to cooperate does this obligation end and is the housing association allowed to reject the ex-offender without offering any alternative.

Besides the ad hoc denial of rental applicants based on their past criminal or anti-social behaviour, Dutch ex-offender's housing rights are sometimes restricted in a more systematic manner as well. Most housing providers, for instance, require their applicants to provide information concerning their rental history by producing a reference from a previous landlord. ${ }^{20}$ In addition to the use of these verhuurdersverklaringen, multiple housing associations

\footnotetext{
${ }^{17}$ See article 45 (2)(f) Dutch Housing Act

${ }^{18}$ District Court Midden-Nederland 1 July 2015, ECLI:NL:RBMNE:2015:4865

${ }^{19}$ It remains unclear exactly how much weight should be attached to such feelings.

${ }^{20}$ See the website of the Dutch national tenant association Woonbond: https://www.woonbond.nl/vraagbaak/watverhuurdersverklaring (accessed on 30 January 2019)
} 
have signed special covenants with local authorities and the police, enabling them to screen and exclude rental applicants based on their income and/or criminal or anti-social record. ${ }^{21}$ Usually, the housing association requests the local authorities to issue a 'housing advice' (woonadvies) based on a background check-performed by the police-regarding past incidents. The police then determines the 'housing risk' (woonrisico) and informs the mayor, who in turn qualifies this as either a 'red housing advice' (negative) or a 'green housing advice' (positive). The advice is then send to the housing association, which ultimately decides whether to rent to the applicant. ${ }^{22}$

At least nineteen municipalities are known to be or have been using these covenants to screen and exclude rental applicants, concerning at least 16.500 homes. ${ }^{23}$ According to a study conducted by investigative journalists of the well-respected Dutch television programme Zembla nearly a hundred applicants were refused housing because of a negative screening result (Zembla 2015). However, seeing that not all municipalities using these covenants actually provided data, the number of excluded ex-offenders is probably higher. ${ }^{24}$ In 2015 , the Dutch government decided that the use of the covenants is no longer allowed due to privacy reasons. ${ }^{25}$ However, in that same year the Dutch legislator provided a statutory basis for local authorities to perform background checks in certain urban areas by extending the 2005 Urban Areas Special Measures Act (Wet bijzondere maatregelen grootstedelijke problematiek). This controversial act is discussed in section 7 of this paper.

\section{Housing Ex-Offenders II: Findings From an Administrative Law Perspective}

The above showed that Dutch ex-offenders may sometimes - with or without good reasonalso experience exclusion by housing providers because of their past criminal or anti-social activities. However, for some ex-offenders finding suitable accommodation is even more problematic. Their arrival or presence in the neighbourhood has such an impact on the community that it results in social unrest or even in public order disturbances. This is often the case with serious violent or sex-offenders, especially when minors are involved or when the (family of the) victim still lives in the area (Boone et al. 2014; Huls and Brouwer 2013).

An assessment of available literature and case law reveals that in such situations local authorities in the Netherlands may adopt three different approaches to maintain or restore public order and to protect residents' (feelings of) safety. Most authorities first approach the (ex-)offender and try to convince him or her not to settle in the municipality. If the (ex-)offender cannot be persuaded to move or settle elsewhere, mayors sometimes use their

\footnotetext{
${ }^{21}$ A covenant is a non-legally binding agreement between two or more parties. It appears that private housing providers have not signed any such agreements: Kamerstukken II 2015/16, 34,314, nr. 3, pp. 3-4.

${ }_{22}$ Most covenants are based on a model drawn up by the National Platform Neighbourhood Nuisance (Landelijk Platform Woonoverlast): http://www.platformwoonoverlast.n1/files/2015/03/voorbeeld-convenant-screening.pdf (accessed on 30 January 2019).

${ }^{23}$ Kamerstukken II 2015/16, 34,314, nr. 3, pp. 1-2

${ }^{24}$ One should also take into account the possibility that people with a history of criminal or anti-social behaviour no longer apply for social housing in these areas because they expect a negative screening result.

${ }^{25}$ According to the Dutch government, the screening of rental applicants lacked a sufficient legal basis and constituted a violation of applicants' right to respect for their private life and privacy: Kamerstukken II 2015/16, 34,314, nr. 3, p. 4; Kamerstukken I 2015/16, 34,314, nr. C, p. 2.
} 
administrative powers to issue an area exclusion order to prevent or end the ex-offender's presence in the area. A last method—-seldom applied - is to rely on private law.

\section{The informal approach}

The first approach most local authorities adopt is to try to convince the ex-offender in an informal way not to (re) establish him- or herself in the municipality. In exchange, the exoffender is usually offered alternative housing (Boone et al. 2014; Huls and Brouwer 2013, p. 20). While regarded by local authorities as the "most obvious" option (Huls and Brouwer 2013 , p. 20), its chances of success ultimately depend on the ex-offender's cooperativeness. Interestingly enough, though, most of these 'controversial' ex-offenders refuse to come to any agreement with the local authorities and appear very persistent in their wish to return to their old neighbourhood (Boone et al. 2014, pp. 51, 67). ${ }^{26}$

Also problematic is that this approach lacks a statutory basis which is required by European human rights law; it is partly because of this that it remains unclear how local authorities generally aim to convince the ex-offender. What arguments are brought to the table in order to persuade the ex-offender to accept the mayor's offer? A case from 2008 seems to provide reason to be sceptic. ${ }^{27}$ The applicant in this case had reported himself to the police after committing a sexual crime with a minor. Within 24 hours, two police officers handed him a prewritten letter addressed to his landlord, stating, among others, that the applicant wished to end his tenancy agreement. The applicant signed the statement, but later argued before the court that he never really wanted to move out of his home. According to the applicant, he was tired and confused at the time of the signing of the letter and was, therefore, incapable of overseeing the consequences this would have for him. The court agreed and concluded that the housing provider had taken advantage of the circumstances the applicant found himself in. ${ }^{28}$

It can be concluded that while the informal approach is apparently used by local authorities and is potentially successful, much is unclear about the (perhaps pressing) arguments and methods used to convince the ex-offender to cooperate. What is known, however, is that if the mayor cannot come to an agreement with the ex-offender, it is in principle not possible to prevent the ex-offender from moving (back) to the municipality (Huls and Brouwer 2013). In such cases, local authorities regularly employ a different, more repressive strategy, using their administrative powers.

\section{Using area exclusion orders to keep the ex-offender out}

Article 172 (3) of the Dutch Municipalities Act provides that "[i] $n$ the event of a public breach of the peace or a serious fear of such a breach, the mayor may issue such orders as are deemed necessary to maintain public order". This may include area exclusion orders, used to ban a person from a certain area in the municipality. The aim of this provision is to enable a swift reaction to an unexpected and urgent situation. According to settled case law, however, issuing

\footnotetext{
${ }^{26}$ See District Court Midden-Nederland 8 April 2015, ECLI:NL:RBMNE:2015:2329; District Court The Hague 6 October 2014 ECLI:NL:RBDHA:2014:12142; District Court The Hague 12 August 2013, ECLI:NL:RBDHA:2013:10154; District Court 's-Hertogenbosch 5 August 2010, ECLI:NL:RBSHE:2010:BN3313

${ }^{27}$ District Court Utrecht 9 April 2008, ECLI:NL:RBUTR:2008:BC8995

28 The case was brought before the civil court, so the local authorities' methods were not reviewed.
} 
an area exclusion order to prevent an ex-offender from (re) settling in the area or to force him or her to leave the area constitutes an inappropriate use of this administrative power.

A case from 2010 illustrates this and provides the reasoning behind it. ${ }^{29}$ It revolves around a paedophile sex-offender who, after completing his prison sentence, returns to his old home. After acting provocatively towards his neighbours - who in turn distribute leaflets showing a picture of the applicant with the caption "active paedophile in our neighbourhood"- the local authorities try to offer him alternative housing. The applicant, however, refuses to cooperate. To prevent further disturbances of the public order the mayor issues an area exclusion order, prohibiting the applicant to be in the municipality for as long as there are no concrete arrangements with the probation service regarding his resocialisation.

The court rules that although the mayor was entitled to issue the order, it did not meet the requirements of Article 2 of the Fourth Protocol to the ECHR. According to the court, an area exclusion order may be in place no longer than absolutely necessary and the area it covers should be as limited as much as possible. Considering that the order in this case would remain in place for as long as there are no arrangements concerning the applicant's resocialisation, the court concludes that it is de facto unclear as to when the order will cease to exist; it essentially lasts for an indefinite period of time. Moreover, the designated area covers the entire municipality, whereas an order covering the applicant's neighbourhood would have sufficed. The court, therefore, rules that the area exclusion order was disproportionate and as such, quashes the mayor's decision to issue it. Seeing that other courts have ruled in similar ways, exoffenders have been able to successfully challenge the use of area exclusion orders to ban him or her from the neighbourhood. This option, therefore, cannot be regarded as providing local authorities with a sustainable solution for the difficulties they may face when an ex-offender arrives in or returns to their municipality.

\section{Using Private Law}

If the use of other methods has failed, local authorities sometimes refer to private law as a last resort, for instance, by requesting the civil court to evict the ex-offender from his or her home. ${ }^{30}$ Of course, this is only possible when the municipality owns the accommodation and seeing that Dutch municipalities possess only a fraction of all rental homes in the Netherlands, this is seldom the case. Another possibility is for the mayor to act as a representative of his or her citizens and ask the court to impose certain measures on the ex-offender, for instance, a prohibition of residence or an area exclusion order. ${ }^{31}$ To support this claim, the mayor could argue that the ex-offender would commit a wrongful act towards his or her neighbours if he or she would (re) settle in the neighbourhood. However, this rather experimental approach has been turned down by a Dutch court in $2015 .{ }^{32}$ According to general principles of Dutch administrative law, authorities in the Netherlands are not allowed to use private law arrangements when public law provides for viable instruments. The use of private law, therefore, does not avail local authorities in trying to restore or maintain public order.

The case law assessment indicates that in situations in which the arrival or presence of an ex-offender offers a threat to the liveability in the neighbourhood - either because of the ex-

\footnotetext{
${ }^{29}$ District Court 's-Hertogenbosch 5 August 2010, ECLI:NL:RBSHE:2010:BN3313

${ }^{30}$ District Court Amsterdam 29 June 2010 (unpublished)

${ }^{31}$ The mayor can base the claim on articles 3:305b and 3:305a Dutch Civil Code

32 District Court Midden-Nederland 6 November 2013, ECLI:NL:RBMNE:2013:5494
} 
offender's own actions or because of neighbourhood residents' reactions - Dutch local authorities sometimes aim to restore public order in the municipality by removing or banning the ex-offender from the area. Whether this is an appropriate or even morally acceptable approach towards such situations does not follow from the examined case law. However, the court decisions discussed above do show that ex-offenders have been able to successfully challenge these approaches before the Dutch courts, which on several occasions have declared the (re) actions of local authorities unlawful.

\section{The Extended 'Rotterdam Act': Ex-offenders' Latest Barrier to Housing?}

In most situations discussed above, ex-offenders' search for housing is frustrated because their arrival or presence directly conflicts with residents' (feelings of) safety or with the public order in the area. However, Dutch law also allows for persons with a history of criminal or antisocial behaviour to be systematically excluded from housing in certain areas, whether they pose a (potential) threat to the neighbourhood or not. Since 2005, it is possible for local authorities in the Netherlands to screen and ban rental applicants from designated urban areas based on their income using the Urban Areas Special Measures Act (hereafter: the Act). ${ }^{33}$ In 2016, this Act was extended to allow for background checks concerning past criminal or antisocial behaviour as well. ${ }^{34}$ Because of the tense relationship of the (extended) Act with various human rights, it is regarded as a piece of legislation both unique ${ }^{35}$ and controversial (Doff 2013; Duivesteijn 2005, p. 2).

The main purpose of the Act is to improve the quality of life in designated inner-city areas facing a concentration of anti-social behaviour. ${ }^{36}$ By regulating the housing supply in these neighbourhoods, existing income segregation should be countered and (further) economic decline and criminal and anti-social behaviour prevented. ${ }^{37}$ While the Act became known as the 'Rotterdam Act' - due to the intensive political lobby of this city — its instruments may be applied in any municipality facing similar problems. ${ }^{38}$

The Act entitles the municipal council to request the Minister for Housing to designate a specific area - or a street or block of buildings - in which rental applicants may be obliged to obtain a special housing permit before being allowed to move into the area. The Minister only designates such an area if he or she deems it necessary and appropriate in order to counter problems specifically occurring in urban areas (grootstedelijke problematiek) and if this meets the criteria of subsidiarity and proportionality. The municipal council also has to guarantee the availability of sufficient affordable homes in the region, so as to make sure that home seekers who do not qualify for a housing permit still maintain ample opportunity to find housing elsewhere in the vicinity of the city. ${ }^{39}$

Once an area has been designated by the Minister-for a period of 4 years, with possible extensions of up to 20 years in total - the municipal council has to enact a housing allocation

\footnotetext{
${ }^{33}$ Wet bijzondere maatregelen grootstedelijke problematiek, Stb. 2005, no. 726

3423 August 2016, Stb. 2016, no. 329. See Kamerstukken II 2015/16, 34,314, nr. 3, p. 4

35 Only the USA (see, e.g., 42 U.S.C § 1437d and 24 C.F.R. § 5.903) and Denmark (see the lov om almene boliger m.v.) seem to have similar legal provisions in place that allow for the screening and banning of people from certain areas.

${ }^{36}$ Kamerstukken II 2004/05, 30,091, nr. 3, p. 6

${ }^{37}$ Kamerstukken II 2004/05, 30,091, nr. 3, p. 12

${ }^{38}$ Kamerstukken II 2004/05, 30,091, nr. 3, p. 3

${ }^{39}$ Kamerstukken II 2004/05, 30,091, nr. 3, p. 14
} 
bye-law in which the obligation to obtain a housing permit is laid down. To qualify for such a permit, one may have to have lived in the municipality for at least 6 years or meet the income criteria provided in the Act. Moreover, he or she may be subjected to a background check concerning (past) criminal and anti-social behaviour. For this, the municipal council can choose between a screening based on a Certificate of Good Conduct (CGC) or on a check of the police registers. ${ }^{40}$ If the rejection of an application results in a clearly unreasonable and unfair situation, the board of mayor and councillors may issue the permit based on a hardship clause.

In 2012, the Act was evaluated. ${ }^{41}$ It appeared that the City of Rotterdam was the only municipality using its instruments. ${ }^{42}$ Other municipalities indicated that they considered the measures unnecessary and disproportionate to the existing problems. A more elaborate evaluation conducted in 2015 concluded that the Act did not have the desired effects (Hochstenbach et al. 2015). Excluding people based on their income did not result in any reduction of criminal or anti-social behaviour in the designated areas. The researchers furthermore observed a 'waterbed effect': rejected applicants settled in neighbouring districts, thus, increasing the influx of so-called "underprivileged persons" (Gemeente Rotterdam 2003, pp. 6-8) in these areas. In spite of these results, however, the Dutch legislator decided to extend the Act. ${ }^{43}$ As of July 2018, eight municipalities are using the 'Rotterdam Act', most of them applying the instruments provided by the extended Act.

Several cases have been published concerning the use of the instruments of the 'Rotterdam Act', although as of January 2019, no judicial decision has yet been produced concerning the use of criminal background checks. In most cases, rental applicants challenge the decision not to invoke the hardship clause. As a consequence, no court has (of yet) declared the instruments of the Act unlawful.

With its recent extension, the Rotterdam Act has become more and more focused on the exclusion of ex-offenders (in the narrow as well as in the broader sense). It provides a clear example of state authorities trying to control crime using non-criminal law instruments. However, the question remains how this systematic screening and excluding of ex-offenders by local authorities relates to their human rights obligations.

\section{A Final Analysis: The Dutch Approach from a Human Rights Perspective}

It has been concluded that citizens have both a moral and a legal right to be protected against (threats of) harm as well as a right to quietly enjoy their home. For ex-offenders, the most important rights in the context of this study are their housing rights: the right to have access to adequate housing and to choose where they want to live. How does Dutch private and administrative law take these - often conflicting - fundamental rights into account when dealing with returning ex-offenders?

When assessing the discussed case law, one can conclude that although some of the Dutch approaches towards the housing of ex-offenders appear at odds with the state's human rights

\footnotetext{
${ }^{40}$ Whereas a CGC is a relatively easy way to gain insights into a person's criminal history, a background check based on police registers also provides data concerning acts that have been reported to the police but did not result in criminal proceedings (Kamerstukken II 2015/16, 33,314, nr. 3, pp. 35, 37-38).

${ }^{41}$ Kamerstukken II 2011/12, 33,340, nr. 1, pp. 6-17

${ }^{42}$ Kamerstukken II 2011/12, 33,340, nr. 1, p. 2

${ }^{43}$ Kamerstukken II 2015/16, 34,314, nr. 3, p. 4
} 
obligations, there seem to be no out-right violations of fundamental rights. The findings presented in section 5 of this paper first of all show that Dutch housing providers sometimes request the court to annul the tenancy agreement and to evict the incarcerated ex-offender if he or she is no longer able to use the premise as a primary residence. Because eviction constitutes a serious interference with a person's right to respect for his or her home, Article 8 ECHR requires a careful weighing of all relevant interests and circumstances. Dutch courts appear to rule in line with this requirement. If they conclude that there has been a shortcoming in the fulfilment of the tenancy agreement, they will grant the landlord's request, unless the (ex-)offender argues that there are exceptional circumstances that should be taken into account. If so, the courts will perform a weighing of interests; in case the eviction has disproportionate consequences, the housing provider's request will be denied. By carefully considering the proportionality of the measure, Dutch courts ensure that ex-offenders' housing rights are sufficiently protected.

A similar conclusion can be drawn when assessing Dutch case law concerning housing providers' rejection of rental applicants with a history of criminal or anti-social behaviour. Dutch courts require social housing providers to weigh all relevant interests and circumstances and if the housing association decides that residents' safety weighs heavier than the exoffender's need for housing, it is allowed to reject his or her application for a home. However, due to their responsibility to accommodate those who experience difficulties finding suitable housing, Dutch courts require (social) housing providers to offer rejected ex-offenders alternative accommodation. As such, both community residents' safety and ex-offenders' right to housing are ensured as much as possible.

The paper also considered Dutch administrative law and, among others, local authorities' use of area exclusion orders to prevent ex-offenders from (re) settling in the municipality. It is clear that these orders interfere with the ex-offender's right to freedom of residence and Dutch courts have on several occasions ruled against the use of this instrument. Referring mainly to Article 2 of the Fourth Protocol to the ECHR, the courts have concluded that orders that are not (sufficiently) restricted in space and time violate the right to freedom of residence. By doing so, Dutch courts adequately protect ex-offenders' rights and interests against unjustifiable interferences.

Notwithstanding the Dutch practices and policies that are in line with human rights requirements, there are some approaches in the Netherlands that do appear problematic from a human rights point of view. One notable example is the extended Rotterdam Act, which clearly restricts ex-offenders' right to freedom of residence. Whether it also violates their housing rights remains unclear, although the European Court of Human Rights did declare the 2005 Act in accordance with Article 2 of the Fourth Protocol to the ECHR. In Garib v. the Netherlands, ${ }^{44}$ it ruled that the decisions made by the Dutch legislator at the time of the drafting of the Act were not manifestly without reasonable foundation. Moreover, the Court considered that the measures provided by the Act are both temporarily and geographically limited and that it has several safeguards build into it, for instance, the hardship clause.

It should, however, be stressed that the Court only reviewed the use of the income criteria and did not consider the screening and banning of rental applicants based on their past behaviour. The criteria used by the Grand Chamber to assess the 2005 Rotterdam Act nevertheless provide a framework with which to assess the 2016 extended Act in light of Article 2, Fourth Protocol to the ECHR. Assuming that the quality of the law-making process

${ }^{44}$ ECHR 6 November 2017 (Grand Chamber), no. 43494/09 (Garib v. the Netherlands) 
is sufficient and considering that the Court grants the national legislator a wide margin of appreciation when implementing social and economic policies, it is likely that the ECtHR will view the legislator's judgement concerning the necessity of the Act's instruments not manifestly without reasonable foundation. Banning people with a record of criminal or anti-social behaviour from certain urban areas using the extended Rotterdam Act's instruments therefore has a good chance to stand the Court's test. ${ }^{45}$

This is probably not the case with the (now unlawful) use of the screening covenants discussed in section 5 of this paper. Although these covenants provide for the screening of rental applicants based on their criminal or anti-social behaviour-just as the extended Rotterdam Act - it does not offer the same safeguards as the Act. Besides lacking a hardship clause, the Dutch government does not appear to have implemented any measures to protect rental applicants against the use of these unlawful background checks. One can of course challenge the covenant in court, but there have been no judicial decisions yet in which a court has reviewed a screening covenant. It consequently remains unclear what level of protection against these interferences with ex-offenders' housing rights is provided in the Netherlands.

A last practice that appears to be at odds with the state's human rights obligations is local authorities' method of informally persuading an ex-offender to move to a different municipality. Firstly, the approach lacks a clear statutory basis which is required by European human rights law. Secondly, much remains unknown about this practice: it is, for example, entirely unclear what (perhaps pressing) arguments or methods are being used to convince the exoffender to cooperate. It is therefore impossible to assess whether this 'black box' approach is in accordance with human rights.

Altogether it seems that Dutch private and administrative law concerning the housing of exoffenders is largely in accordance with human rights. There are no indications of any flagrant violation of ex-offenders' or community residents' rights and freedoms. However, several policies and practices do appear problematic and much about these approaches remains unknown.

\section{Discussion and Conclusions}

This paper presented an explorative study of the often conflicting obligations private and administrative actors face when trying to accommodate an ex-offender. In recent years, the housing of ex-offenders has received increased attention from law practitioners, policy makers, and scholars. While it is now undisputed that stable accommodation plays a vital role in the reintegration process of every ex-offender; it has time and again been demonstrated that finding adequate housing remains problematic. The few studies on landlords' attitudes towards ex-offenders suggest that they are often stigmatised and regarded as unreliable tenants. Other studies, such as the one conducted by Carey in 2004, address the role of government authorities in protecting residents by preventing ex-offenders from moving into the neighbourhood. The study presented here combines both perspectives by determining the extent to which ex-offenders' and community residents' rights and interests are being

\footnotetext{
$\overline{45}$ The use of background checks may nevertheless violate other fundamental rights such as the right to nondiscrimination (Article 14 ECHR). Although Ms Garib did rely on this provision as well, she only invoked it before the Grand Chamber. Arguing that she should have done so at an earlier stage in the legal proceedings, the Grand Chamber refused to consider the Rotterdam Act in light of this provision: Garib v. the Netherlands, para. 102.
} 
considered within the context of Dutch private and administrative law. To allow for such an analysis, human rights documents, and social contract theory have been used to construct a normative framework which is not only applicable to the Netherlands, but can be used to review policies and practices in other countries as well.

In addition to the conceptualisation of this human rights framework, the adoption of a new, broader definition of the term '(ex-)offender' has been suggested. Seeing the shift from the use of criminal sanctions towards law enforcement using other (legal) instruments, there is an increasing number of people who experience similar exclusions from vital aspects of (social) life, but who nevertheless remain unrepresented in our studies. The adoption of a broader definition prevents these individuals from falling outside the scope of our research, though it also raises new questions. What are, for instance, the consequences of bringing individuals with distinct reintegration needs and facing various degrees of difficulty finding a home all under the scope of the term '(ex-)offender'? Such issues shall be addressed when further developing this idea, and future theorisation on the '(ex-)offender' concept is advocated by the author.

Lastly, the findings discussed above show that Dutch private and administrative law does not appear to explicitly violate ex-offenders' or community residents' human rights. Nevertheless, the doctrinal legal analysis presented in this paper does indicate that certain practices are at least at odds with the state's human rights obligations. Unfortunately, too little is known about these approaches to be able to draw sufficiently substantiated conclusions. To gain a more comprehensive understanding of, among others, the use of the (unlawful) screening covenants and the informal ways of convincing an ex-offender to (re) settle elsewhere, empirical research is needed. This paper provided a groundwork for this and should consequently act as a stepping stone for future studies into the Dutch housing situation of exoffenders. It should furthermore serve as an incentive for researchers outside the Netherlands to conduct more research on ex-offenders' housing needs in relation to community safety.

Open Access This article is licensed under a Creative Commons Attribution 4.0 International License, which permits use, sharing, adaptation, distribution and reproduction in any medium or format, as long as you give appropriate credit to the original author(s) and the source, provide a link to the Creative Commons licence, and indicate if changes were made. The images or other third party material in this article are included in the article's Creative Commons licence, unless indicated otherwise in a credit line to the material. If material is not included in the article's Creative Commons licence and your intended use is not permitted by statutory regulation or exceeds the permitted use, you will need to obtain permission directly from the copyright holder. To view a copy of this licence, visit http://creativecommons.org/licenses/by/4.0/.

\section{References}

Adams, K. D. (2009). Do we need a right to housing? Nevada Law Journal, 9(2), 275-324.

Alfredsson, G. S., \& Eide, A. (1999). The universal declaration of human rights: A common standard of achievement. The Hague: Martinus Nijhoff Publishers.

Baldry, E., McDonnell, D., Maplesston, P., \& Peeters, M. (2006). Ex-prisoners, homelessness and the state in Australia. The Australian and New Zealand Journal of Criminology, 39(1), 20-33.

Boone, M. M., Van de Bunt, H. G., \& Siegel, D. (2014). Gevangene van het verleden. Crisissituaties na de terugkeer van zedendelinquenten in de samenleving. Amsterdam: Reed Business.

Bradley, K. H., Micheal Oliver, R. B., Richardson, N. C., \& Slayter, E. M. (2001). No place like home: Housing and the ex-prisoner. Boston: Community Resources for Justice. 
Bröring, H. E., \& Keulen, B. F. (2017). Bestraffende sancties in het strafrecht en het bestuursrecht. Paris: Zutphen.

Bruijn, L. M., Vols, M., \& Brouwer, J. G. (2018). Home closure as a weapon in the Dutch war on drugs: Does judicial review function as a safety net? International Journal of Drug Policy, 51, 137-147.

Bushway, S. D., Stoll, M. A., \& Weiman, D. F. (2007). Barriers to reentry? The labor market for released prisoners in post-industrial America. New York: Russell Sage Foundation.

Cain, H. L. (2003). Housing our criminals: Finding housing for the offender in the twenty-first century. Golden Gate University Law Review, 33(2), 131-171.

Carey, A. (2004). No second chance: People with criminal records denied access to public housing. New York: Human Rights Watch.

CESCR (UN Committee on Economic, Social and Cultural Rights), General Comment No. 4: The Right to Adequate Housing (Art. 11 (1) of the Covenant), 13 December 1991, E/1992/23.

Clark, L. M. (2007). Landlord attitudes toward renting to released offenders. Federal Probation, 71(1).

Council of Europe. (2008). Housing policy and vulnerable social groups. Strasbourg: Council of Europe Publishing.

Crowell, H. (2017). A home of One's own: The fight against illegal housing discrimination based on criminal convictions, and those who are still left behind. Texas Law Review, 95(5), 1103-1144.

Crowther, C. (2007). An introduction to criminology and criminal justice. New York: Palgrave Macmillan.

Dirkzwager, A., Blokland, A., Nannes, K., \& Vroonland, M. (2015). Effecten van detentie op het vinden van werk en een woning. Tijdschrift voor Criminologie, 57(1), 5-30.

Doff, W. (2013). Rotterdam zet symboolpolitiek door. Tijdschrift voor de Volkshuisvesting, 2013(5), 6-16.

Duivesteijn, A. (2005). De Rotterdamwet deugt niet. $S \& D$, 2005(10).

Elbers, J. M., Weggemans, D., \& Liem, M. C. A. (2016). Op Vrije Voeten: Herintreding van Maatschappelijk Gevoelige Ex-gedetineerden. The Hague: Campus Den Haag.

Garland, D. (2001). The culture of control. Crime and social order in contemporary society. Oxford: Oxford University Press.

Gemeente Rotterdam (2003). Rotterdam zet door. Op weg naar een stad in balans. Rotterdam: Gemeente Rotterdam.

Hobbes, T. (1981). Leviathan. London: Penguin Books.

Hochstenbach, C., Uitermark, J., \& Van Gent, W. (2015). Evaluatie effecten Wet bijzondere maatregelen grootstedelijke problematiek ("Rotterdamwet") in Rotterdam. Amsterdam: Amsterdam Institute for Social Science Research.

Hohmann, J. (2013). The right to housing. Law, concepts, possibilities. Oxford: Hart Publishing.

HRC (UN Human Rights Committee), CCPR General Comment No. 27: Article 12 (Freedom of Movement), 2 November 1999, CCPR/C/21/Rev.1/Add.9.

Huls, C. E., \& Brouwer, J. G. (2013). De terugkeer van zedendelinquenten in de wijk. Amsterdam: Reed Business.

Hutchinson, T., \& Duncan, N. (2012). Defining and describing what we do: Doctrinal legal research. Deakin Law Review, 17(1).

Kenna, P. (2008). Housing rights: Positive duties and enforceable rights at the European court of human rights. European Human Rights Law Review, 13(2), 193-208.

Klein, S. R. (1999). Redrawing the criminal-civil boundary. Buffalo Criminal Law Review, 2(2), 681-723.

Kucs, A., Sedlova, Z., \& Pierhurovica, L. (2008). The right to housing: International, European and National Perspectives. Cuadernos Constitucionales de la Cátedra Fadrique Furió Ceriol, 64(65), 101-123.

Lammar-Heindel, C.S. (2012). Does the state have moral duties? State duty-claims and the possibility of institutionally held moral obligations. Iowa Research Online. https://ir.uiowa.edu/cgi/viewcontent. cgi?article=3388\&context=etd. Accessed 5 Feb 2019.

Lindesmith, A. R., \& Warren Dunham, H. (1941). Some principles of criminal typology. Social Forces, 19(3).

Locke, J. (1993). The second treatise of government. London: Everyman.

Mann, K. (1992). Punitive civil sanctions: The Middleground between criminal and civil law. The Yale Law Journal, 101(8).

Metraux, S., \& Culhane, D. P. (2004). Homeless shelter use and incarceration following prison release. Criminology \& Public Policy, 3(2), 139-160.

Moore, K. E., Stuewig, J. B., \& Tangney, J. P. (2016). The effect of stigma on criminal offenders' functioning: A longitudinal Mediational model. Deviant Behavior, 37(2), 196-218.

More, A., \& Weijters, G. (2011). Detentie en de ongewenste gevolgen voor inkomen en huisvesting van gedetineerden. PROCES, 90(1).

Nelson, M., Dees, P., \& Allen, C. (2011). The first month out: Post-incarceration experiences in New York City. Federal Sentencing Reporter, 24(1). 
OHCHR (UN Office of the High Commissioner for Human Rights), Fact Sheet No. 21, The Human Right to Adequate Housing 2009, Fact Sheet No. 21/Rev.1.

Olds, K. (2010). The role of courts in making the right to housing a reality throughout Europe: Lessons from France and the Netherlands. Wisconsin International Law Journal, 28(1).

Rainey, B., Wicks, E., \& Ovey, C. (2017). Jacobs, white, and Ovey: The European convention on human rights. Oxford: Oxford University Press.

Rechtspraak (2017). Kengetallen gerechten 2017, via https://www.rechtspraak.nl/Organisatie-encontact/Organisatie/Raad-voor-de-rechtspraak/Jaardocumenten. Accessed 8 Sept 2019.

Roman, C. G., \& Travis, J. (2006). Where will I sleep tomorrow? Housing, homelessness, and the returning prisoner. Housing Policy Debate, 17(2), 389-418.

Rousseau, J. (2003). On the social contract. Mineola: Dover Publications.

Tyler, T. R. (2017). Methodology in legal research. Utrecht Law Review, 13(2).

Van der Vorm, B. (2018). Rechtsbescherming tegen de cumulatie van privaatrechtelijke en strafrechtelijke gebiedsverboden. Juridische Verkenningen, 2018(2), 41-57.

Van Tongeren, J. H. S., \& Vols, M. (2018). The right to housing and the right to a second chance: How Dutch landlords and local authorities facilitate and frustrate the successful reintegration of ex-offenders. In J. Sidoli \& M. Vols (Eds.), People and buildings: Comparative housing law (pp. 171-190). Den Haag: Eleven Publishing.

Vols, M. (2015). Artikel 8 EVRM en de gedwongen ontruiming van de huurwoning vanwege overlast. WR, 2015(16), 55-62.

Vols, M. (2019). European law and private evictions: Property, proportionality and vulnerable people. European Review of Private Law, 27(4), 719-752.

Wacks, R. (2017). Understanding jurisprudence. An introduction to legal theory. Oxford: Oxford University Press.

Weijters, G., Rokven, J. J., \& Verweij, S. (2018). Monitor nazorg (ex-)gedetineerden - meting 5. Den Haag: WODC.

Zembla (2015). Burenruzie, via https://zembla.bnnvara.nl/nieuws/burenruzie (accessed 8 Sept 2019).

Publisher's Note Springer Nature remains neutral with regard to jurisdictional claims in published maps and institutional affiliations. 